\title{
PERANAN AUDIT INTERNAL DALAM MENUNJANG EFEKTIVITAS PENGENDALIAN INTERNAL ATAS BIAYA PRODUKSI AIR MINUM DALAM KEMASAN 240ML PADA PT. AQUA GOLDEN MISSISSIPPI TBK.
}

\author{
Arief Tri Hardiyanto \\ Dosen Tetap Fakultas Ekonomi Universitas Pakuan \\ Amelia Megarachmawati \\ Mahasiswa Fakultas Ekonomi Universitas Pakuan
}

\begin{abstract}
ABSTRAK
Penelitian ini mengenai bagaimana peranan audit internal yang memadai dapat berperan dalam menunjang efektivitas pengendalian internal atas biaya produksi air minum dalam kemasan 240ml pada PT. Aqua Golden Mississippi Tbk. (Cabang Mekarsari). Metode yang digunakan dalam penelitian ini adalah metode descriptive statistic dengan menggunakan koefisien korelasi Rank Spearman dengan $\mathrm{n}=15$ dan tingkat signifikan sebesar 0,05. Berdasarkan hasil penelitian yang telah diuraikan, maka dapat disimpulkan bahwa jawaban responden dalam peranan audit internal yang memadai memberikan jawaban sangat setuju dan setuju sebesar $96,1 \%$, jawaban responden mengenai efektivitas pengendalian internal atas biaya produksi sebesar $97,02 \%$ menjawab sangat setuju dan setuju. Peranan audit internal dalam menunjang efektivitas pengendalian internal atas biaya produksi air minum dalam kemasan 240ml termasuk sangat kuat, yaitu $89,96 \%$. Sedangkan sisanya sebesar $10,04 \%$ dipengaruhi oleh faktor-faktor lain yang tidak termasuk dalam penelitian yang dilakukan oleh penulis. Dengan demikian dapat dikatakan bahwa audit internal yang memadai sangat berperan dalam menunjang efektivitas pengendalian internal atas biaya produksi air minum dalam kemasan $240 \mathrm{ml}$ pada PT. Aqua Golden Mississippi Tbk. (Cabang Mekarsari).
\end{abstract}

Kata Kunci: Audit Internal, Pengendalian Internal, Biaya Produksi

\begin{abstract}
This study shows how the role of internal audit is adequate can play a role in supporting the effectiveness of internal controls over the production cost of bottled water 240ml at PT. Aqua Golden Mississippi Tbk. (Branch Mekarsari). The method used in this research is descriptive statistic by using Spearman Rank correlation coefficient with $n=15$ and a significant level of 0.05. Based on the research that has been described, it can be concluded that the respondents in the role of internal audit is adequately provide answers strongly agree and agree amounting to $96.1 \%$ of respondents regarding the effectiveness of internal control over production costs by $97.02 \%$ answered strongly agree and agree, The role of internal audit in supporting the effectiveness of internal controls over the production cost of bottled water $240 \mathrm{ml}$ including a very strong, which is $89.96 \%$. While the remaining $10.04 \%$ influenced by other factors not included in the research conducted by the author. Thus it can be said that adequate internal audit was instrumental in supporting the effectiveness of internal controls over the production cost of bottled water 240ml at PT. Aqua Golden Mississippi Tbk. (Branch Mekarsari).
\end{abstract}

Keywords: Internal Audit, Internal Control, Cost of Production

\section{Pendahuluan}

Audit Internal merupakan salah satu divisi/bagian yang bertugas untuk melakukan fungsi kontrol terhadap aktivitas kegiatan pada PT. Aqua Golden Mississippi Tbk.

PT. Aqua Golden Mississippi Tbk. adalah perusahaan yang bergerak di bidang industri air minum dalam 
kemasan (AMDK) di Indonesia. Kegiatan PT. Aqua Golden Mississippi Tbk. adalah mengolah bahan mentah menjadi barang jadi, oleh karena itu efisiensi dan efektivitas menjadi salah satu tujuan yang harus dicapai. Pengawasan terhadap aktivitas produksi pada PT. Aqua Golden Mississippi Tbk. menjadi salah satu hal yang sangat penting.

Dalam rangka mencapai tujuan tersebut audit internal berfungsi melaksanakan tugas pimpinan untuk melakukan penilaian secara independen dan profesional untuk memastikan tercapainya tujuan organisasi.
Biaya produksi pada PT. Aqua Golden Mississippi sangat dibutuhkan terutama dalam pembiayaan suatu produk perusahaan. Pengendalian atas biaya produksi ini sangat membantu perusahaan dalam mencapai tujuan perusahaan, memelihara serta mempertahankan operasionalisasi yang efektif sehingga tidak menyimpang dari apa yang telah ditetapkan oleh pimpinan perusahaan. Tabel 1 berikut ini merupakan tabel Cost of Goods Manufacture (COGM) Air Minum Dalam Kemasan 240ml pada PT. Aqua Golden Mississippi Tbk.:

Tabel 1

Cost of Goods Manufacture (COGM)

Air Minum Dalam Kemasan 240ml

LOCAL 1X48 LOCAL 1 X48 LOCAL 1X48

(2012) (2013) (2014)

\begin{tabular}{|c|c|c|c|c|c|c|c|}
\hline \multirow{3}{*}{$\begin{array}{l}\text { Descriptions } \\
\text { PRODUCTION }\end{array}$} & \multicolumn{3}{|c|}{1020000004} & \multicolumn{2}{|c|}{1020000004} & \multicolumn{2}{|c|}{74548} \\
\hline & CAR/BTL & & p $1,336,586$ & & $\operatorname{Rp} 1,284,640$ & & Rp 1,265,668 \\
\hline & LITER & & $15,397,471$ & & p $14,799,053$ & & p $14,580,495$ \\
\hline MATERIAL COST & Rupiah & Rp10,2 & $233,672,728$ & $\mathrm{Rp}$ 1 & $, 301,269,220$ & Rp1 & $1,813,128,431$ \\
\hline $\begin{array}{l}\text { MANUFACTURING } \\
\text { LABOR COST }\end{array}$ & Rupiah & $\mathrm{Rp} 1,2$ & $222,453,321$ & $\mathrm{Rp}$ & $991,569,979$ & $\mathrm{Rp}$ & $1,228,694,947$ \\
\hline $\begin{array}{l}\text { DIRECT } \\
\text { PRODUCTION } \\
\text { COST }\end{array}$ & Rupiah & $\mathrm{Rp}$ & $800,671,841$ & $\mathrm{Rp}$ & $, 041,269,721$ & $\mathrm{Rp}$ & 1,810,916,106 \\
\hline $\begin{array}{l}\text { MANUFACTURING } \\
\text { OVERHEAD COST }\end{array}$ & Rupiah & $\mathrm{Rp}$ & $914,250,913$ & $\mathrm{Rp}$ & $664,540,074$ & $\mathrm{Rp}$ & $725,315,785$ \\
\hline TOTAL COGM & Rupiah & Rp13,1 & 171,048,803 & $\mathrm{Rp}$ ] & $, 998,648,993$ & Rp1 & $5,578,055,269$ \\
\hline $\begin{array}{l}\text { Actual Cost per } \\
\text { UOM }\end{array}$ & Rupiah & $\mathrm{Rp}$ & 9,854 & $\mathrm{Rp}$ & 10,119 & $\mathrm{Rp}$ & 12,308 \\
\hline Std Cost per UOM & Rupiah & $\mathrm{Rp}$ & 9,160 & $\mathrm{Rp}$ & 8,753 & $\mathrm{Rp}$ & 10,173 \\
\hline Variance & Rupiah & $\mathrm{Rp}$ & 694 & $\mathrm{Rp}$ & 1,366 & $\mathrm{Rp}$ & 2,135 \\
\hline & $\%$ & & $8 \%$ & & $16 \%$ & & $21 \%$ \\
\hline
\end{tabular}

Sumber: PT. Aqua Golden Mississippi Tbk. (Cabang Mekarsari), 2015

Dilihat dari Tabel 1, Cost of Goods Manufacture (COGM) untuk air kemasan 240ml dari tahun 2012 s/d 2014 mengalami kenaikan dan penurunan per- akhir tahun. Pada akhir Desember 2012 Cost Of Goods Manufacture (COGM) sebesar Rp13.171.048.803, kemudian terjadi penurunan Cost of Goods 
Manufacture (COGM) pada Desember 2013 yaitu sebesar Rp12.998.648.993, dan pada Desember 2014 terjadi kenaikan kembali yakni sebesar Rp15.578.055.269.

Hal tersebut dapat disimpulkan bahwa, meskipun pencapaian pada PT. Aqua Golden Mississippi Tbk. (Cabang Mekarsari) telah disesuaikan dengan SOP (Standar Operasional Prosedur) yang berlaku, namun hal tersebut tidak menutup kemungkinan dipengaruhi oleh beberapa faktor lain, salah satunya adalah faktor eksternal perusahaan. Oleh karena itu perlu dilakukan pengendalian biaya, baik biaya produksi, biaya administrasi, maupun biaya pemasaran yang dikeluarkan oleh perusahaan. Diantara ketiga komponen tersebut, komponen biaya produksi merupakan komponen biaya yang terbesar diantara yang lainnya. Oleh karena itu biaya produksi harus mendapat prioritas utama dalam pengendalian, agar pemakaian dalam biaya produksi dapat dipertanggungjawabkan dan dapat tercapainya tujuan yang telah ditentukan oleh perusahaan.

Pengendalian internal pada PT. Aqua Golden Mississippi Tbk. terdiri dari kebijakan dan prosedur yang ditetapkan sesuai dengan Audit Internal Control untuk memberikan keyakinan yang memadai bahwa tujuan perusahaan akan dicapai. Karenanya harus diciptakan suatu sistem, prosedur, dan kebijaksanaan untuk menolong perusahaan mandapatkan jaminan dan pengamanan bahwa transaksi yang dijalankan sah dan dicatat secara wajar.

Walaupun pengendalian atas biaya produksi telah ada, keberadaan audit internal tetap diperlukan karena suatu sistem pengendalian internal mungkin akan kurang berfungsi apabila tidak ada alat untuk mengawasi dan mengevaluasi sistem tersebut. Audit internal akan memberikan bantuan bagi pimpinan dan manajemen perusahaan dalam menjaga, meningkatkan, dan menilai keefektifan pengendalian atas biaya produksi pada perusahaan. Audit internal sangat dibutuhkan perusahaan dalam pengendalian atas biaya produksi karena apabila terjadi kesalahan dalam melakukannya maka akan mengakibatkan keadaan yang sangat merugikan bagi perusahaan.

Ada pun tujuan penelitian ini adalah sebagai berikut:

1. Untuk mengetahui pelaksanaan audit internal pada PT. Aqua Golden Mississippi Tbk. (Cabang Mekarsari).

2. Untuk mengetahui efektivitas pengendalian internal atas biaya produksi air kemasan $240 \mathrm{ml}$ pada PT. Aqua Golden Mississippi Tbk. (Cabang Mekarsari).

3. Untuk mengetahui bagaimana peranan audit internal dalam menunjang efektivitas pengendalian internal atas biaya produksi air kemasan 240ml pada PT. Aqua Golden Mississippi Tbk. (Cabang Mekarsari).

\section{Tinjauan Pustaka}

2.1. Audit Internal

Definisi internal audit yaitu: (IIA'S Board of Directors)

"Internal audit is an independent, objective assurance and consulting activities designed to add value and improve organization's operations. It's helps an organization accomplish its objective by bringing a systematic, diciplined approach to evaluate and inprove the efectiveness of risk management, control and processes." 
Dari definisi tersebut dapat diartikan bahwa audit internal adalah kegiatan assurance dan konsultasi yang independen dan objektif, yang dirancang untuk memberikan nilai tambah dan meningkatkan kegiatan operasi organisasi. Definisi tersebut juga lebih menekankan kepada audit internal untuk membantu organisasi dalam mencapai tujuannya, melalui pendekatan yang sistematis dan teratur untuk mengevaluasi dan meningkatkan efektivitas pengelolaan risiko, pengendalian dan proses governance yang berkaitan dengan:

1. Keandalan dan integritas dari informasi financial dan operasional;

2. Efektivitas dan efesiensi operasi;

3. Pengamanan aktiva;

4. Ketaatan terhadap peraturan, regulasi, dan kontrak.

Audit internal dilakukan oleh orang yang berasal dari dalam organisasi yang bersangkutan, yang disebut dengan auditor internal. Keberadaan profesi auditor internal didalam suatu organisasi membantu perusahaan mencapai tujuan dengan pendekatan yang sistematis dan ketat agar dapat melakukan evaluasi dan peningkatan efektivitas terhadap manajmen resiko, pengendalian dan proses tata kelola (Elder dkk, 2011:450).

\subsubsection{Tujuan dan Ruang Lingkup Audit Internal}

Tujuan audit internal yang dikemukakan oleh The Institute of Internal Auditors dan dikutip oleh Boynton et al (2001:980) adalah sebagai berikut:

"It helps an organization
accomplish its objectives by
bringing a systematic,
disciplined, approach to
evaluate and improve the
effectiveness of risk

management, control, and governance process."

Dari definisi di atas, dapat diartikan bahwa tujuan audit yaitu membantu semua tingkatan manajemen dalam melaksanakan tanggung jawabnya, membantu pencapaian tujuan perusahaan dan memberikan nilai tambah dalam mengevaluasi kinerja perusahaan dan upaya perbaikannya dengan memberikan pelayanan berupa pemberian saran untuk memperbaiki kinerja bagi setiap level manajer.

Jadi, ruang lingkup audit mencangkup pengujian dan evaluasi kelayakan dan efektivitas pengendalian internal yang digunakan perusahaan serta kualitas hasil pekerjaan dan hasil pelaksanaan tanggungjawab yang dibebankan guna membantu pihak manajemen dalam mengawasi dan mengevaluasi berjalannya roda suatu organisasi.

\subsubsection{Peranan Audit Internal}

Peranan audit internal yang dikemukakan Ardeno Kurniawan (2012:53) adalah:

"Peranan audit internal adalah memberikan berbagai macam jasa kepada organisasi termasuk audit kinerja dan audit operasional yang akan dapat membantu manajemen senior dan dewan komisaris didalam memantau kinerja yang dihasilkan oleh manajemen dan para personil didalam organisasi sehingga auditor internal dapat memberikan penilaian yang independen mengenai seberapa baik kinerja organisasi."

Peranan audit internal bagi seorang internal audit yaitu keberadaannya (eksistensinya), mengembangkan dan mempertahankan staf auditor internal 
yang berkualitas dalam jumlah yang sesuai dengan sifat dan ukuran perusahaan, menerapkan program audit yang pantas, yang dirancang untuk memastikan keandalan pengendalian internal perusahaan dan melaporkannya secara periodik kepada dewan komisaris atau direktur utama.

\subsection{Pengendalian Internal}

Setiap perusahaan mempunyai tujuan, baik itu jangka pendek, jangka menengah, maupun jangka panjang, dimana tujuan dari setiap perusahaan membutuhkan sistem dan pengelolaan yang cermat.

Pengendalian internal memainkan peranan penting tentang bagaimana manajemen memenuhi pelayanan atau tanggung jawab lembaga.Manajemen memiliki tanggung jawab untuk mempertahankan pengendalian yang memberikan assurance yang memadai bahwa pengendalian yang memadai ada atas asset dan catatan entitas.Tanpa adanya pengendalian internal, tujuan perusahaan tidak dapat dicapai secara efektif dan efisien.Semakin besar perusahaan, semakin penting pula arti dari pengendalian internal dalam perusahaan tersebut.

COSO (2013:13) mendefinisikan pengendalian internal sebagai berikut:

"Internal control is a
process, effected by an
entity's board of directors,
manage-ment, and other
personel, designed to
providereasonable
assurance regarding the
achievement of objectives
relating to operations,
reporting, and compliance."

\subsubsection{Tujuan Pengendalian Internal}

Tujuan pengendalian internal yaitu mencakup 3 (tiga) hal pokok yang dapat diuraikan sebagai berikut:
1. Tujuan-tujuan operasi yang berkaitan dengan efektivitas dan efisiensi operasi entitas, termasuk tujuan kinerja operasional dan keuangan, dan untuk menjaga asset dari kerugian, yang dimana bahwa pengendalian internal dimaksudkan untuk meningkatkan efektivitas dan efisiensi dari semua operasi perusahaan sehingga dapat mengendalikan biaya yang bertujuan untuk mencapai tujuan organisasi.

2. Tujuan-tujuan pelaporan, bahwa pengendalian internal dimaksudkan untuk meningkatkan keandalan data serta catatan-catatan akuntansi yang berkaitan dengan kepentingan pelaporan keuangan baik untuk kalangan internal maupun eksternal yang memenuhi kriteria andal, tepat waktu, transparan, dan persyaratanpersyaratan lain yang ditetapkan oleh pemerintah, pembuat standarstandar yang diakui, ataupun kebijakan-kebijakan entitas sehingga tidak menyesatkan pemakai laporan tersebut dan dapat diuji kebenarannya.

3. Tujuan-tujuan ketaatan terhadap hukum dan peraturan yang berlaku dengan mana entitas merupakan subjeknya, bahwa pengendalian internal dimaksudkan untuk meningkatkan ketaatan entitas terhadap hukum-hukum dan peraturan yang telah ditetapkan pemerintah, pembuat aturan terkait, maupun kebijakan entitas itu sendiri.

Ketiga tujuan tersebut merupakan hasil (output) dari suatu pengendalian internal yang baik, yang dapat dicapai dengan memperhatikan unsure-unsur pengendalian internal yang merupakan proses untuk menghasilkan pengendalian internal yang baik. Oleh karena itu, agar tujuan pengendalian internal tercapai, maka perusahaan harus 
mempertimbangkan unsur-unsur pengendalian internal.

\subsubsection{Komponen/Unsur-Unsur Pengendalian Internal}

COSO (2013:4) menyatakan mengenai unsure-unsur pengendalian internal sebagai berikut:

1. Lingkungan Pengendalian (Control Environment)

$\mathrm{COSO}$

menjelaskan mengenai komponen lingkungan pengendalian (control environment) sebagai seperangkat standar, proses, dan struktur yang memberikan dasar untuk melaksanakan pengendalian internal diseluruh organisasi. Lingkungan pengendalian terdiri dari:
a. Integritas dan nilai etika organisasi,

b. Parameter-parameter pelaksanaan tugas dan tanggung jawab direksi dalam mengelola organisasinya,

c. Struktur organisasi, tugas, wewenang dan tanggung jawab,

d. Proses untuk menarik, mengembangkan, dan mempertahankan individu yang kompeten, dan

e. Ketegasan mengenai tolak ukur kinerja insentif, dan penghargaan untuk mendorong akuntabilitas kinerja.

2. Penilaian Risiko (Risk Assessment) Berdasarkan rumusan COSO, bahwa penilaian risiko melibatkan proses yang dinamis dan interaktif untuk mengidentifikasi dan menilai risiko terhadap pencapaian tujuan. Risiko itu sendiri dipahami sebagai suatu kemungkinan bahwa suatu peristiwa akan terjadi dan mempengaruhi tujuan entitas dan risiko terhadap pencapaian seluruh tujuan dari entitas ini dianggap relative terhadap toleransi risiko yang diterapkan. Oleh karena itu, penilaian risiko membentuk dasar untuk menentukan bagaimana risiko harus dikelola oleh organisasi.

3. Aktivitas Pengendalian (Control Activities).

$$
\text { Aktivitas pengendalian }
$$

adalah tindakan-tindakan yang ditetapkan melalui kebijakankebijakan dan prosedur-prosedur yang membantu memastikan bahwa arahan manajemen untuk mengurangi risiko terhadap pencapaian tujuan dilakukan. Aktivitas pengendalian dilakukan pada semua entitas, pada berbagai tahap dalam proses bisnis, dan atas lingkungan teknologi.

4. Informasi dan Komunikasi (Information and Communications). $\mathrm{COSO}$ (2013:5) menjelaskan mengenai komponen informasi dan komunikasi (information and communications) dalam pengendalian internal sebagai informasi sangat penting bagi setiap entitas untuk melaksanakan tanggung jawab pengendalian internal guna mendukung pencapaian tujuan-tujuannya. Informasi yang diperlukan oleh manajemen adalah informasi yang relevan dan berkualitas baik yang berasal dari sumber internal maupun eksternal dan informasi digunakan untuk mendukung fungsi komponen-komponen lain dari pengendalian internal. Informasi diperoleh atau dihasilkan melalui komunikasi antar pihak internal maupun eksternal yang dilakukan secara terus-menerus, berulang, dan berbagi.

5. Pengawasan (Monitoring).

Aktivitas pemantauan merupakan kegiatan evaluasi dengan beberapa bentuk apakah yang 
sifatnya berkelanjutan, terpisah, ataupun kombinasi keduanya yang digunakan untuk memastikan apakah masing-masing dari kelima komponen, ada dan berfungsi. Kegiatan pemantauan meliputi proses penilaian kualitas kinerja pengendalian intern sepanjang waktu, dan memastikan apakah semuanya dijalankan seperti apa yang diinginkan, serta apakah telah disesuaikan dengan perubahan keadaan. Dari hasil kegiatan pemantauan tersebut dapat ditemukan kelemahan dan kekurangan pengendalian sehingga dapat diusulkan pengendalian yang lebih baik.

\subsection{Biaya Produksi}

\subsubsection{Pengertian Biaya Produksi}

Salah satu pengelompokkan biaya berdasarkan produknya adalah biaya produksi. Biaya produksi dapat diartikan sebagai biaya yang digunakan dalam proses produksi yang terdiri dari biaya bahan baku/bahan baku langsung, biaya tenaga kerja langsung, dan biaya overhead pabrik. Biaya produksi ini disebut juga dengan biaya produk yaitu biaya-biaya yang dapat dihubungkan dengan suatu produk, dimana biaya ini merupakan bagian dari persediaan.

Menurut Riwayandi
(2006:64) menyatakan
bahwa:
"Biaya produksi adalah biaya
yang terjadi pada fungsi
produksi, dimana fungsi
produksi merupakan fungsi
yang mengolah bahan baku
menjadi barang jadi".

Sedangkan menurut Firdaus dan Wasilah (2009:42) menyatakan bahwa:

"Biaya produksi merupakan biaya yang terjadi sehubungan dengan kegiatan manufaktur atau memproduksi suatu barang terdiri atas bahan langsung, tenaga kerja langsung, dan overhead pabrik".

Berdasarkan beberapa pengertian diatas maka dapat disimpulkan bahwa biaya produksi merupakan sejumlah biaya yang harus dikeluarkan oleh perusahaan untuk proses produksi. Biaya produksi terdiri atas bahan baku langsung, tenaga kerja langsung, dan biaya overhead pabrik.

\subsubsection{Tujuan Penentuan Biaya Produksi}

Penentuan harga pokok produksi bertujuan untuk mengetahui berapa besarnya biaya yang dikorbankan dalam hubungannya dengan pengolahan bahan baku menjadi barang jadi atau jasa yang siap untuk dijual dan dipakai. Penentuan harga pokok sangat penting dalam suatu perusahaan, karena merupakan salah satu elemen yang dapat digunakan sebagai pedoman dan sumber informasi bagi pimpinan dalam mengambil keputusan.

Menurut Akbar (2011), adapun tujuan penentuan harga pokok produksi yang lain, diantaranya yakni:

1. Sebagai dasar untuk menilai efisiensi perusahaan.

2. Sebagai dasar dalam penentuan kebijakan pimpinan perusahaan.

3. Sebagai dasar penilaian bagi penyusun neraca yang menyangkut penilaian terhadap aktiva.

4. Sebagai dasar untuk menetapkan harga penawaran atau harga jual terhadap konsumen.

5. Menentukan nilai persediaan dalam neraca, yaitu harga pokok persediaan produk jadi.

6. Untuk menghitung harga pokok produksi dalam laporan laba rugi perusahaan.

7. Sebagai evaluasi hasil kerja. 
8. Pengawasan terhadap efisiensi biaya, terutama biaya produksi.

9. Sebagai dasar pengambilan keputusan.

10. Untuk tujuan perencanaan laba.

\section{Sistem Perhitungan Biaya Produksi}

Sistem perhitungan biaya bertujuan untuk menentukan biaya dari barang atau jasa yang dihasilkan oleh perusahaan. Perhitungan biaya membebankan sejumlah biaya ke setiap produk sedemikian rupa sehingga merefleksikan biayadari sumber daya yang digunakan untuk memproduksi produk tersebut. Menurut Carter dan Usry (2006:127) yang dialih bahasakan oleh Krista, sistem perhitungan biaya produksi yang paling banyak digunakan terbagi atas dua, yaitu :

\section{Sistem Perhitungan Biaya \\ Berdasarkan Pesanan (Job Order Cost Method).}

Sistem perhitungan biaya berdasarkan pesanan biasanya digunakan apabila produk yang diproduksi bersifat heterogen. Dalam perhitungan biaya berdasarkan pesanan mengakumulasikan biaya bahan baku langsung, tenaga kerja langsung, dan biaya overhead yang dibebankan ke setiap pesanan. Sebagai hasilnya, perhitungan biaya berdasarkan pesanan dapat dipandang dalam tiga bagian yang saling berhubungan. Akuntansi bahan baku memelihara catatan persediaan bahan baku, membebankan bahan baku langsung ke pesanan, dan membebankan bahan baku tidak langsung ke overhead. Akuntansi tenaga kerja memelihara akun-akun yang berhubungan dengan beban gaji, membebankan tenaga kerja langsung ke pesanan dan membebankan tenaga kerja tidak langsung ke overhead. Akuntansi overhead mengakumulasi biaya overhead, memelihara catatan terinci atas overhead dan membebankan sebagian dari overhead ke pesanan.

2. Sistem Perhitungan Biaya Berdasarkan Proses (Process Cost Method).

Perhitungan biaya berdasarkan proses, biasanya digunakan apabila produksi yang diproduksi bersifat homogen. Dalam perhitungan biaya berdasarkan proses, bahan baku, tenaga kerja, dan overhead pabrik dibebankan ke pusatbiaya. Biaya yang dibebankan ke setiap unit ditentukan dengan membagi total biaya yang dibebankan ke pusat biaya dengan total unit yang diproduksi. Jika produk dari suatu proses menjadi bahan baku dari proses berikutnya, maka biaya per unit dihitung untuk setiap proses.

\section{Penentuan Biaya Produksi}

Harga pokok produksi merupakan beban pokok produksi dengan memperhitungkan saldo awal dan saldo akhir barang dalam proses produksi. (IAI,2004:163). Perhitungan harga pokok produksi dapat ditentukan sebelum proses produksi selesai dengan menggunakan actual cost sistem.

Dua metode penentuan harga pokok adalah penetapan harga pokok serapan (absorption costing)/metode full costing dan penetapan harga pokok variabel (variable costing), yaitu:

a. Metode Harga Pokok Serapan (Absorption Costing): Metode harga pokok serapan atau metode full costing adalah metode penentuan harga pokok produk, dimana biaya overhead pabrik tetap diikutkan dalam biaya yang dapat dimasukkan dalam persediaan harga pokok produk yang diperhitungkan meliputi 
biaya bahan baku langsung, tenaga kerja langsung, overhead pabrik variabel dan overhead pabrik tetap.

b. Metode Harga Pokok Variabel (Variable Costing): Metode harga pokok variabel adalah penentuan harga pokok produksi dimana overhead pabrik tetap dikeluarkan dari biaya yang dapat dimasukkan sebagai persediaan. Harga pokok produk yang diperhitungkan meliputi biaya bahan baku langsung, tenaga kerja langsung, dan overhead pabrik variabel.

\subsection{Hipotesis Penelitian}

$H_{o}$ : Audit internal yang tidak memadai belum berperan dalam menunjang efektivitas pengendalian internal atas biaya produksi

$H_{a}$ : Audit internal yang memadai berperan dalam menunjang efektivitas pengendalian internal atas biaya produksi

\section{Metodologi Penelitian}

3.1. Objek Penelitian

Objek penelitian yang terdapat di dalam penelitian ini adalah peranan audit internal dalam menunjang efektivitas pengendalian internal atas biaya produksi, pada PT. Aqua Golden Mississippi Tbk. (Cabang Mekarsari). Dimana Peranan audit internal sebagai variabel Independen, dan Pengendalian Internal atas biaya produksi sebagai variabel dependen.

Unit analisis yang digunakan dalam penelitian ini adalah organization, yaitu sumber data yang unit analisisnya berdasarkan informasi dari divisi organisasi/perusahaan. Dalam hal ini unit analisisnya adalah PT. Aqua Golden Mississsippi Tbk (Cabang Mekarsari).

Penelitian dilakukan di PT. Aqua Golden Mississippi Tbk. (Cabang
Mekarsari). Perusahaan ini berlokasi di J1. Raya Siliwangi No 70. Desa Mekarsari, Cicurug, Sukabumi, Jawa Barat.

\subsection{Metode Pengolahan/Analisis Data}

Metode analisis yang digunakan oleh penulis adalah descriptive statistics.

1. Analisis Deskriptif

Yaitu data yang diperoleh dan dikelompokkan, kemudian dianalisis berdasarkan metode yang telah ditetapkan yang bertujuan untuk mengetahui berperan atau tidaknya audit internal dalam menunjang efektivitas pengendalian internal atas biaya produksi.

2. Analisis Statistik

Yaitu digunakan untuk menguji anggapan dasar yang masih bersifat dasar sehingga masih dapat ditarik kesimpulan statistic mengenai diterima atau ditolaknya hipotesis.

Pengujian hipotesis dilakukan dengan cara menghitung presentase yang menunjukkan seberapa besar peranan audit internal dalam menunjang efektivitas pengendalian internal atas biaya produksi.

\subsection{Rancangan Pengolahan Data dan Pengujian Hipotesis}

Setelah data yang diperoleh terkumpul, kemudian dianalisis berdasarkan teori yang telah ditetapkan untuk menentukan hipotesis yang dikemukakan oleh penulis dapat di terima dan teruji, yaitu audit internl berpengaruh secara signifikan dari peranan audit internal dalam menunjang efektivitas pengendalian internal atas biaya produksi. Dalam pengujian hipotesis di tolak, adalah apabila kenyataan sebaliknya. Setelah itu penulis dapat menarik kesimpulan atas hipotesis yang telah dilakukan. 
Dalam pengujian hipotesis, data yang dikumpulkan diperoleh melalui kuisioner variabel independen dan variabel dependen yang diberikan kepada responden. Adapun kuisioner yang digunakan penulis dalam pengumpulan data terdiri dari dua bagian, yaitu:

1. Pertanyaan Umum

Pertanyaan umum dibuat dalam bentuk pertanyaan terbuka, menyangkut identitas responden, diantaranya: nama, jabatan, pendidikan terakhir, lama bekerja, yang kemungkinan jawabannya tidak ditentukan terlebih dahulu dan responden bebas menentukan jawabannya.

2. Pertanyaan Khusus

Pertanyaan khusus adalah pertanyaan yang berhubungan dengan "Peranan Audit Internal Dalam Menunjang Efektivitas Pengendalian Internal Atas Biaya Produksi" dalam bentuk pertanyaan tertutup, yaitu dengan menggunakan variasi jawaban yang sudah ditentukan terlebih dahulu. Setiap item dari kuisioner tersebut memiliki lima jawaban yang masing-masing berbeda nilainya, dan untuk menentukan skor atau nilai dari jawaban kuisioner, penulis menggunakan Skala Likert.

Berdasarkan pernyataan diatas, maka penulis menetapkan nilai-nilai jawaban sebagai berikut:

- Sangat Setuju = 5

- Setuju = 4

- Ragu-Ragu = 3

- Tidak Setuju = 2

- Sangat Tidak Setuju $=1$

Untuk setiap variabel tersebut ditetapkan indikatornya masing-masing, atas dasar indikator ini disusun sejumlah pertanyaan untuk memperoleh jawaban berupa data-data tentang pelaksanaan setiap variabel tersebut sesuai dengan hipotesis yang telah diungkapkan penulis.

\section{Hasil dan Pembahasan}

\subsection{Peranan Audit Internal Yang} Memadai

Di bawah ini penulis akan mengemukakan hasil pengumpulan data mengenai peranan audit internal yang memadai dengan indikator - indikator: kriteria audit internal, program audit internal, pemeriksaan dan evaluasi audit internal, mengkomunikasikan hasil audit internal, tindak lanjut hasil audit, kode etik audit internal, lingkungan pengendalian, penaksiran risiko, informasi dan komunikasi, aktivitas pengendalian, dan pengawasan.

1. Kriteria Audit Internal

a. Independensi

Berdasarkan hasil kuisioner, audit internal pada PT. Aqua Golden Mississippi Tbk (Cab. Mekarsari) memiliki pengetahuan dan keahliantelah diberi tanggung jawab serta wewenang dalam mengemukakan pendapatnya dengan bebas dalam melaksanakan tugasnya. Hal ini didasarkan pada hasil jawaban $51,67 \%$ responden yang menyatakan sangat setuju, $41,67 \%$ responden yang menyatakan setuju, dan $6,66 \%$ responden yang menyatakan ragu-ragu.

b. Kompetensi

Berdasarkan hasil kuisioner, audit internal yang bertugas pada PT. Aqua Golden Mississippi Tbk. (Cab. Mekarsari) memiliki pengetahuan dan keahlian yang memadai dalam melaksanakan tugasnya. Hal ini didasarkan pada hasil jawaban $46,67 \%$ responden yang menyatakan sangat setuju, dan 53,33\% responden yang menyatakan setuju.

2. Pelaksanaan Audit Internal

a. Program Audit 
Berdasarkan hasil kuisioner, program audit pada PT.Aqua Golden Mississippi Tbk. (Cab. Mekarsari) telah dinyatakan dengan ringkas dan mudah dimengerti. Hal ini didasarkan pada hasil jawaban 51,11\% responden yang menyatakan sangat setuju, $56,67 \%$ responden yang menyatakan setuju, dan $2,22 \%$ responden yang menyatakan ragu-ragu.

b. Pemeriksaan Dan Evaluasi Informasi

Berdasarkan hasil kuisioner, pemeriksaan dan evaluasi audit internal dilaksanakan berdasarkan jadwal audit yang telah ditetapkan oleh PT.Aqua Golden Mississippi Tbk. (Cab. Mekarsari), serta sesuai dengan apa yang diprogramkan sebelumnya. Hal ini didasarkan pada hasil jawaban 43,33\% responden yang menyatakan sangat setuju, 53,33\% responden yang menyatakan setuju, dan $3,34 \%$ responden yang menyatakan ragu-ragu.

c. Mengkomunikasikan Hasil

Berdasarkan hasil kuisioner, audit internal pada PT.Aqua Golden Mississippi Tbk. (Cab. Mekarsari) telah mengkomunikasikan hasil audit secara tertulis, ringkas, jelas serta dapat dipercaya. Hal ini didasarkan pada hasil jawaban $41,67 \%$ responden yang menyatakan sangat setuju, $53,33 \%$ respondenyang menyatakan setuju, dan 5\% responden yang menyatakan ragu - ragu.

d. Tindak Lanjut

Berdasarkan hasil kuisioner, manajemen dan audit internal pada PT.Aqua Golden
Mississippi Tbk. (Cab. Mekarsari) telah menerima perkembangan perbaikan mengenai tindak lanjut atas laporan dari manajemen secara periodik. Hal ini didasarkan pada hasil jawaban 50\% responden yang menyatakan sangat setuju, $46,67 \%$ responden yang menyatakan setuju, dan 3,33\% responden yang menyatakan ragu - ragu.

\subsection{Efektivitas Pengendalian Internal Atas Biaya Produksi}

1. Unsur-unsur Pengendalian Internal

a. Lingkungan Pengendalian

Berdasarkan hasil kuisioner, PT. Aqua Golden Mississippi Tbk. (Cab. Mekarsari), memiliki kode etik dan kebijakan perusahaan dijadikan pedoman kinerja personel, serta memiliki pengendalian untuk mengurangi penyelewengan atau penyimpangan yang terjadi. Hal ini didasarkan pada hasil jawaban $45,45 \%$ responden yang menyatakan sangat setuju, $50,30 \%$ responden yang menyatakan setuju, dan 4,25\% responden yang menyatakan ragu - ragu.

b. Penaksiran Risiko

Berdasarkan hasil kuisioner, manajemen pada PT. Aqua Golden Mississippi Tbk. (Cab. Mekarsari) telah mengurangi dan mengantisipasi risiko yang dihadapi. Hal ini didasarkan pada hasil jawaban 48,33\% responden yang menyatakan sangat setuju dan $51,67 \%$ responden menyatakan setuju.

c. Aktivitas Pengendalian

Berdasarkan hasil kuisioner, pada PT. Aqua Golden Mississippi Tbk. (Cab. Mekarsari), terdapat 
pengendalian secara fisik dan terkomputerisasi. Hal ini didasarkan pada hasil jawaban $44,44 \%$ responden yang menyatakan sangat setuju, $44,44 \%$ responden yang menyatakan setuju, dan 11,12\% responden yang menyatakan ragu - ragu.

d. Informasi dan Komunikasi Berdasarkan hasil kuisioner, PT. Aqua Golden Mississippi Tbk. (Cab. Mekarsari) menggunakan informasi sebagai alat pengambilan keputusan dalam mengelola dan mengendalikan kegiatan perusahaan secara efektif. Hal ini didasarkan pada hasil jawaban $45,33 \%$ responden yang menyatakan sangat setuju, $50,67 \%$ responden yang menyatakan setuju, dan $4 \%$ responden yang menyatakan ragu - ragu.

e. Pengawasan

Berdasarkan hasil kuisioner, pengawasan atau pemantauan pada PT.Aqua Golden Mississippi Tbk. (Cab. Mekarsari) dilakukan langsung oleh setiap atasan terhadap bawahannya pada semua level organisasi. Hal ini didasarkan pada hasil jawaban 53,33\% responden yang menyatakan sangat setuju dan $46,67 \%$ responden yang menyatakan setuju.

2. Pengendalian Biaya Produksi

a. Prosedur Biaya Bahan Baku

Berdasarkan hasil kuisioner, bagian-bagian yang terkait dengan pengendalian bahan baku pada PT. Aqua Golden Mississippi Tbk. (Cab. Mekarsari) telah melakukan pengajuan pembelian bahan baku, pemeriksaan bahan baku, dan pencatatan penerimaan bahan baku secara tepat. Hal ini didasarkan pada hasil jawaban $45 \%$ responden yang menyatakan sangat setuju 50\% responden yang menyatakan setuju, dan $5 \%$ responden yang menyatakan ragu - ragu.

b. Prosedur Biaya Tenaga Kerja Langsung

Berdasarkan hasil kuisioner, PT. Aqua Golden Mississippi Tbk. (Cab. Mekarsari) memiliki daftar hadir tenaga kerja serta pencatatan waktu kerja untuk penentuan pembayaran gaji dan upah. Hal ini didasarkan pada hasil jawaban $40 \%$ responden yang menyatakan sangat setuju, $56 \%$ responden yang menyatakan setuju, dan $4 \%$ responden yang menyatakan ragu - ragu.

c. Prosedur Biaya Overhead Pabrik Berdasarkan hasil kuisioner, PT. Aqua Golden Mississippi Tbk. (Cab. Mekarsari), telah melakukan prosedur pencatatan dan perhitungan biaya overhead pabrik dengan tepat dan efektif. Hal ini didasarkan pada hasil jawaban $42,67 \%$ responden yang menyatakan sangat setuju dan $57,33 \%$ responden yang menyatakan setuju.

d. Prosedur Produk Selesai

Berdasarkan hasil kuisioner, PT. Aqua Golden Mississippi Tbk. (Cab. Mekarsari), telah melakukan langkah-langkah tepat untuk prosedur produk pesanan yang telah selesai dikerjakan. Hal ini didasarkan pada hasil jawaban $40 \%$ responden yang menyatakan sangat setuju dan $60 \%$ responden yang menyatakan setuju.

\subsection{Analisis Pengujian Hipotesis}


Analisis ini dilakukan dengan tujuan untuk menganalisis dan mengevaluasi mengenai oeranan audit internal dalam menunjang efektivitas pengendalian internal atas biaya produksi. Untuk itu perlu dilakukan pengujian hipotesis yang dikemukakan sebelumnya, yaitu: "Audit internal yang memadai berperan dalam menunjang efektivitas pengendalian internal atas biaya produksi". Langkah - langkah untuk menguji hipotesis yaitu:

1. Penetapan Hipotesis Penelitian

Hipotesis penelitian ini tediri dari hipotesis nol $\left(H_{O}\right)$ dengan hipotesis alternatif $\left(H_{a}\right)$, yang ada pada penelitian ini adalah:

$>H_{o}: \mu=0$, Tidak ada pengaruh yang signifikan dari peranan audit internal dalam menunjang efektivitas pengendalian internal atas biaya produksi.
$>H_{a}: \mu=0$, Terdapat pengaruh yang signifikan dari peranan audit internal dalam menunjang efektivitas pengendalian internal atas biaya produksi.

2. Pemilihan Tes Statistik dan Perhitungannya

Untuk memberikan kebenaran hipotesis yang telah dikemukakan, dilakukan pengujian statistik dengan cara menghitung koefisien korelasi Rank Spearman antara variabel $\mathrm{X}$ dan variabel Y.

Variabel $\mathrm{X}$ (Peranan audit internal yang memadai) yaitu variabel independen. Penulis mendapatkan hasil dari kuisioner yang disebarkan 1 (satu) eksemplar untuk setiap responden yang berada di PT. Aqua Golden Mississippi Tbk. (Cab. Mekarsari), adapun hasil kuisioner "Peranan Audit Internal Yang Memadai" yang tersaji berikut ini:

Tabel 11

Hasil Kuisioner

Peranan Audit Internal Yang Memadai

\begin{tabular}{|c|c|c|c|c|c|c|c|c|c|c|c|c|c|c|c|c|}
\hline \multirow{2}{*}{ No. } & \multicolumn{15}{|c|}{ Responden } & \multirow{2}{*}{ Total } \\
\hline & A & B & C & $\mathrm{D}$ & $\mathrm{E}$ & $\mathrm{F}$ & G & $\mathrm{H}$ & I & $\mathrm{J}$ & $\mathrm{K}$ & $\mathrm{L}$ & $\mathrm{M}$ & $\mathrm{N}$ & $\mathrm{O}$ & \\
\hline 1 & 5 & 4 & 5 & 4 & 3 & 4 & 5 & 4 & 5 & 3 & 4 & 4 & 4 & 5 & 5 & 64 \\
\hline 2 & 5 & 5 & 5 & 3 & 3 & 4 & 4 & 5 & 5 & 4 & 5 & 4 & 5 & 4 & 5 & 66 \\
\hline 3 & 5 & 5 & 5 & 4 & 4 & 4 & 5 & 4 & 5 & 4 & 5 & 4 & 4 & 5 & 5 & 68 \\
\hline 4 & 5 & 5 & 5 & 4 & 5 & 4 & 4 & 5 & 5 & 4 & 5 & 4 & 4 & 5 & 5 & 68 \\
\hline 5 & 4 & 5 & 5 & 4 & 4 & 4 & 4 & 5 & 5 & 4 & 5 & 4 & 5 & 4 & 5 & 67 \\
\hline 6 & 5 & 4 & 5 & 4 & 4 & 4 & 5 & 4 & 5 & 5 & 4 & 4 & 4 & 5 & 5 & 67 \\
\hline 7 & 5 & 5 & 5 & 3 & 5 & 4 & 5 & 4 & 5 & 4 & 4 & 4 & 4 & 5 & 5 & 67 \\
\hline 8 & 4 & 5 & 5 & 4 & 4 & 4 & 4 & 5 & 5 & 4 & 5 & 4 & 4 & 5 & 5 & 67 \\
\hline 9 & 5 & 4 & 5 & 4 & 5 & 4 & 4 & 5 & 5 & 4 & 5 & 4 & 5 & 4 & 5 & 68 \\
\hline 10 & 4 & 4 & 5 & 4 & 4 & 4 & 5 & 4 & 5 & 5 & 5 & 4 & 5 & 4 & 5 & 67 \\
\hline 11 & 5 & 4 & 5 & 4 & 4 & 4 & 5 & 4 & 5 & 4 & 4 & 4 & 4 & 5 & 5 & 66 \\
\hline 12 & 4 & 4 & 5 & 4 & 5 & 4 & 4 & 5 & 5 & 4 & 5 & 4 & 5 & 4 & 5 & 67 \\
\hline 13 & 4 & 3 & 5 & 3 & 4 & 4 & 5 & 4 & 5 & 4 & 5 & 4 & 5 & 4 & 5 & 64 \\
\hline 14 & 4 & 5 & 5 & 4 & 5 & 4 & 5 & 4 & 5 & 4 & 5 & 4 & 4 & 5 & 5 & 68 \\
\hline 15 & 4 & 3 & 5 & 4 & 3 & 4 & 4 & 5 & 5 & 4 & 4 & 4 & 4 & 5 & 5 & 63 \\
\hline 16 & 5 & 3 & 5 & 4 & 4 & 4 & 4 & 5 & 5 & 4 & 4 & 4 & 4 & 5 & 5 & 65 \\
\hline 17 & 4 & 4 & 5 & 4 & 5 & 4 & 5 & 4 & 5 & 4 & 4 & 4 & 4 & 5 & 5 & 66 \\
\hline 18 & 5 & 4 & 5 & 4 & 4 & 4 & 4 & 5 & 5 & 4 & 5 & 4 & 4 & 5 & 5 & 67 \\
\hline 19 & 5 & 4 & 5 & 3 & 5 & 4 & 4 & 5 & 5 & 5 & 5 & 4 & 5 & 4 & 5 & 68 \\
\hline 20 & 5 & 5 & 5 & 4 & 3 & 4 & 5 & 4 & 5 & 4 & 4 & 4 & 5 & 4 & 5 & 66 \\
\hline
\end{tabular}




\begin{tabular}{|c|c|c|c|c|c|c|c|c|c|c|c|c|c|c|c|c|}
\hline 21 & 4 & 5 & 5 & 4 & 4 & 4 & 5 & 4 & 5 & 4 & 5 & 4 & 4 & 5 & 5 & 67 \\
\hline Jumlah & 96 & 90 & 105 & 80 & 87 & 84 & 95 & 95 & 105 & 86 & 97 & 84 & 92 & 97 & 105 & 1396 \\
\hline
\end{tabular}

Variabel Y (Pengedalian internal atas biaya produksi) yaitu variabel dependen, dapat diketahui dari hasil kuisioner yang diserahkan untuk 1 (satu) responden pada PT.
Aqua Golden Mississppi Tbk. (Cab. Mekarsari). Adapun hasil kuisioner "Pengendalian Internal Atas Biaya Produksi", tesaji sebagai berikut:

Tabel 12

Hasil Kuisioner

Pengendalian Internal Atas Biaya Produksi

\begin{tabular}{|c|c|c|c|c|c|c|c|c|c|c|c|c|c|c|c|c|}
\hline \multirow{2}{*}{ No. } & \multicolumn{15}{|c|}{ Responden } & \multirow{2}{*}{ Total } \\
\hline & $\mathrm{A}$ & B & $\mathrm{C}$ & $\mathrm{D}$ & $\mathrm{E}$ & $\mathrm{F}$ & $\mathrm{G}$ & $\mathrm{H}$ & I & $\mathrm{J}$ & $\mathrm{K}$ & $\mathrm{L}$ & $\mathrm{M}$ & $\mathrm{N}$ & $\mathrm{O}$ & \\
\hline 1 & 4 & 4 & 5 & 4 & 4 & 4 & 4 & 5 & 5 & 5 & 5 & 4 & 5 & 4 & 5 & 67 \\
\hline 2 & 5 & 4 & 5 & 4 & 4 & 4 & 5 & 4 & 5 & 4 & 5 & 4 & 5 & 4 & 5 & 67 \\
\hline 3 & 4 & 5 & 5 & 3 & 4 & 4 & 5 & 4 & 5 & 4 & 5 & 4 & 4 & 5 & 5 & 66 \\
\hline 4 & 4 & 4 & 5 & 3 & 4 & 4 & 4 & 5 & 5 & 4 & 5 & 4 & 4 & 5 & 5 & 65 \\
\hline 5 & 5 & 4 & 5 & 4 & 4 & 4 & 4 & 5 & 5 & 4 & 4 & 4 & 5 & 4 & 5 & 66 \\
\hline 6 & 5 & 4 & 5 & 4 & 5 & 4 & 5 & 4 & 5 & 4 & 5 & 4 & 4 & 5 & 5 & 68 \\
\hline 7 & 5 & 4 & 5 & 4 & 5 & 4 & 5 & 4 & 5 & 4 & 5 & 4 & 4 & 5 & 5 & 68 \\
\hline 8 & 5 & 5 & 5 & 4 & 3 & 4 & 4 & 5 & 5 & 4 & 4 & 4 & 5 & 4 & 5 & 66 \\
\hline 9 & 4 & 5 & 5 & 3 & 4 & 4 & 5 & 4 & 5 & 3 & 5 & 4 & 4 & 5 & 5 & 65 \\
\hline 10 & 5 & 4 & 5 & 4 & 4 & 4 & 4 & 5 & 5 & 4 & 5 & 4 & 5 & 4 & 5 & 67 \\
\hline 11 & 4 & 5 & 5 & 4 & 3 & 4 & 5 & 4 & 5 & 4 & 4 & 4 & 5 & 4 & 5 & 65 \\
\hline 12 & 4 & 5 & 5 & 3 & 4 & 4 & 4 & 5 & 5 & 4 & 5 & 4 & 4 & 5 & 5 & 66 \\
\hline 13 & 4 & 5 & 5 & 4 & 4 & 4 & 5 & 4 & 5 & 4 & 4 & 4 & 4 & 5 & 5 & 66 \\
\hline 14 & 5 & 4 & 5 & 4 & 4 & 4 & 5 & 4 & 5 & 4 & 5 & 4 & 5 & 4 & 5 & 67 \\
\hline 15 & 4 & 5 & 5 & 4 & 5 & 4 & 4 & 5 & 5 & 4 & 5 & 4 & 4 & 5 & 5 & 68 \\
\hline 16 & 4 & 5 & 5 & 4 & 5 & 4 & 4 & 5 & 5 & 4 & 4 & 4 & 4 & 5 & 5 & 67 \\
\hline 17 & 4 & 5 & 5 & 4 & 4 & 4 & 5 & 4 & 5 & 5 & 4 & 4 & 4 & 5 & 5 & 67 \\
\hline 18 & 5 & 5 & 5 & 4 & 5 & 4 & 5 & 4 & 5 & 4 & 4 & 4 & 5 & 4 & 5 & 68 \\
\hline 19 & 4 & 4 & 5 & 4 & 5 & 4 & 4 & 5 & 5 & 4 & 4 & 4 & 5 & 4 & 5 & 66 \\
\hline 20 & 4 & 4 & 5 & 3 & 4 & 4 & 5 & 4 & 5 & 4 & 5 & 4 & 5 & 4 & 5 & 65 \\
\hline 21 & 4 & 5 & 5 & 4 & 4 & 4 & 4 & 5 & 5 & 5 & 5 & 4 & 5 & 4 & 5 & 68 \\
\hline 22 & 4 & 3 & 5 & 3 & 4 & 4 & 4 & 5 & 5 & 4 & 5 & 4 & 4 & 5 & 5 & 64 \\
\hline 23 & 4 & 4 & 5 & 3 & 4 & 4 & 5 & 4 & 5 & 4 & 5 & 4 & 4 & 5 & 5 & 65 \\
\hline 24 & 4 & 3 & 5 & 3 & 4 & 4 & 5 & 4 & 5 & 5 & 5 & 4 & 5 & 4 & 5 & 65 \\
\hline 25 & 4 & 3 & 5 & 3 & 4 & 4 & 4 & 5 & 5 & 5 & 5 & 4 & 4 & 5 & 5 & 65 \\
\hline 26 & 5 & 5 & 5 & 4 & 5 & 4 & 4 & 5 & 5 & 4 & 5 & 4 & 4 & 5 & 5 & 69 \\
\hline 27 & 4 & 5 & 5 & 4 & 4 & 4 & 5 & 4 & 5 & 5 & 4 & 4 & 4 & 5 & 5 & 67 \\
\hline 28 & 5 & 5 & 5 & 4 & 4 & 4 & 5 & 4 & 5 & 5 & 4 & 4 & 5 & 4 & 5 & 68 \\
\hline 29 & 5 & 5 & 5 & 3 & 4 & 4 & 4 & 5 & 5 & 5 & 5 & 4 & 5 & 4 & 5 & 68 \\
\hline 30 & 5 & 4 & 5 & 4 & 5 & 4 & 4 & 5 & 5 & 4 & 4 & 4 & 4 & 5 & 5 & 67 \\
\hline 31 & 4 & 3 & 5 & 3 & 4 & 4 & 4 & 5 & 5 & 4 & 4 & 4 & 5 & 4 & 5 & 63 \\
\hline 32 & 4 & 5 & 5 & 4 & 4 & 4 & 4 & 5 & 5 & 4 & 4 & 4 & 4 & 5 & 5 & 66 \\
\hline 33 & 4 & 4 & 5 & 3 & 4 & 4 & 5 & 4 & 5 & 4 & 4 & 4 & 4 & 5 & 5 & 64 \\
\hline 34 & 4 & 4 & 5 & 4 & 4 & 4 & 5 & 4 & 5 & 4 & 4 & 4 & 5 & 4 & 5 & 65 \\
\hline 35 & 5 & 4 & 5 & 4 & 4 & 4 & 5 & 4 & 5 & 4 & 4 & 4 & 4 & 5 & 5 & 66 \\
\hline 36 & 4 & 5 & 5 & 3 & 4 & 4 & 4 & 5 & 5 & 4 & 3 & 4 & 4 & 5 & 5 & 64 \\
\hline 37 & 5 & 4 & 5 & 4 & 4 & 4 & 5 & 4 & 5 & 5 & 5 & 4 & 5 & 4 & 5 & 68 \\
\hline 38 & 4 & 5 & 5 & 4 & 4 & 4 & 5 & 4 & 5 & 4 & 4 & 4 & 5 & 4 & 5 & 66 \\
\hline
\end{tabular}




\begin{tabular}{|c|c|c|c|c|c|c|c|c|c|c|c|c|c|c|c|c|}
\hline 39 & 5 & 4 & 5 & 5 & 4 & 4 & 5 & 4 & 5 & 4 & 4 & 4 & 4 & 5 & 5 & 67 \\
\hline 40 & 4 & 4 & 5 & 4 & 4 & 4 & 5 & 4 & 5 & 4 & 4 & 4 & 5 & 4 & 5 & 65 \\
\hline 41 & 5 & 4 & 5 & 4 & 4 & 4 & 4 & 5 & 5 & 4 & 5 & 4 & 4 & 5 & 5 & 67 \\
\hline 42 & 5 & 4 & 5 & 4 & 4 & 4 & 5 & 4 & 5 & 4 & 5 & 4 & 4 & 5 & 5 & 67 \\
\hline 43 & 5 & 4 & 5 & 4 & 4 & 4 & 5 & 4 & 5 & 4 & 4 & 4 & 4 & 5 & 5 & 66 \\
\hline 44 & 5 & 4 & 5 & 4 & 4 & 4 & 4 & 5 & 5 & 4 & 5 & 4 & 5 & 4 & 5 & 67 \\
\hline 45 & 5 & 4 & 5 & 4 & 4 & 4 & 4 & 5 & 5 & 4 & 4 & 4 & 4 & 5 & 5 & 66 \\
\hline 46 & 5 & 4 & 5 & 4 & 4 & 4 & 5 & 4 & 5 & 4 & 4 & 4 & 4 & 5 & 5 & 66 \\
\hline 47 & 4 & 4 & 5 & 4 & 4 & 4 & 5 & 4 & 5 & 4 & 4 & 4 & 4 & 5 & 5 & 65 \\
\hline Jumlah & 209 & 202 & 235 & 195 & 194 & 188 & 214 & 209 & 235 & 196 & 210 & 188 & 208 & 215 & 235 & 3114 \\
\hline
\end{tabular}

Untuk mengetahui koefisien korelasi Rank Spearman maka digunakan rumus:

$$
r_{s}=1-\frac{6 \sum_{i-1}^{n} d i^{2}}{n\left(n^{2}-n\right)}
$$

Keterangan:

- $r_{s}=$ Koefisien korelasi Rank Spearman

- $\quad d_{i}=$ Selisih rangking data variabel $\mathrm{X}$ dan $\mathrm{Y}(\mathrm{Xi}-\mathrm{Yi})$
- $n=$ Banyaknya Sampel

Sebelum menggunakan rumus diatas, terlebih dahulu ditentukan ranking dari skor perhitungan kuisioner masing - masing variabel. Ranking atas skor perhitungan masing-masing variabel dapat dilihat pada tabel berikut ini:

Tabel 13

Perhitungan Ranking dan Selisih Rangking

\begin{tabular}{|c|c|c|c|c|c|c|}
\hline Responden & $\mathrm{X}$ & $\mathrm{Y}$ & Rank X & Rank Y & $d_{i}$ & $D_{i^{2}}$ \\
\hline $\mathrm{A}$ & 96 & 209 & 6 & 7,5 & $-1,5$ & 2,25 \\
\hline B & 90 & 202 & 10 & 10 & 0 & 0 \\
\hline $\mathrm{C}$ & 105 & 235 & 2 & 2 & 0 & 0 \\
\hline $\mathrm{D}$ & 80 & 195 & 15 & 12 & 3 & 9 \\
\hline $\mathrm{E}$ & 87 & 194 & 11 & 13 & -2 & 4 \\
\hline $\mathrm{F}$ & 84 & 188 & 13,5 & 14,5 & -1 & 1 \\
\hline $\mathrm{G}$ & 95 & 214 & 7,5 & 5 & 2,5 & 6,25 \\
\hline $\mathrm{H}$ & 95 & 209 & 7,5 & 7,5 & 0 & 0 \\
\hline $\mathrm{I}$ & 105 & 235 & 2 & 2 & 0 & 0 \\
\hline $\mathrm{J}$ & 86 & 196 & 12 & 11 & 1 & 1 \\
\hline $\mathrm{K}$ & 97 & 210 & 4,5 & 6 & $-1,5$ & 2,25 \\
\hline $\mathrm{L}$ & 84 & 188 & 13,5 & 14,5 & -1 & 1 \\
\hline $\mathrm{M}$ & 92 & 208 & 9 & 9 & 0 & 0 \\
\hline $\mathrm{N}$ & 97 & 215 & 4,5 & 4 & 0,5 & 0,25 \\
\hline $\mathrm{O}$ & 105 & 235 & 2 & 2 & 0 & 0 \\
\hline \multicolumn{6}{|c|}{ Jumlah } & 27 \\
\hline
\end{tabular}

Berdasarkan data yang diperlihatkan pada tabel 13 maka akan dapat kita ketahui koefisien korelasi Rank Spearman dengan memasukkan data tersebut kedalam rumus berikut:

$$
\begin{array}{r}
r_{S}= \\
1-\frac{6 \sum_{i-1}^{n} d i^{2}}{n\left(n^{2}-n\right)}
\end{array}
$$

Maka:

$$
r_{S}=1-\frac{6(27)}{15\left(15^{2}-15\right)}
$$

$$
\begin{aligned}
& r_{s}=1-\frac{162}{3150} \\
& r_{s}=1-0,0514 \\
& r_{s}=0,9485
\end{aligned}
$$

Koefisien korelasi Rank Spearman antara variabel $\mathrm{X}$ dan variabel $\mathrm{Y}$ yang didapat dari hasil perhitungan diatas adalah 0,9485 atau $94,85 \%$.

Dari tabel 13, dapat dilihat bahwa terdapat beberapa responden yang mempunyai skor yang sama untuk 
variabel $\mathrm{X}$ dan variabel Y. Oleh karena itu harus dikoreksi dengan menggunakan faktor koreksi t, yaitu:

$$
t=\frac{t^{3}-t}{12}
$$

Sehubungan terdapatnya angka yang sama pada berbagai rangking maka faktor koreksi harus dijumlahkan sebagai berikut:

Tabel 14

Variabel X

\begin{tabular}{|r|r|r|r|c|}
\hline \multicolumn{1}{|c|}{$X$} & \multicolumn{1}{|c|}{$T$} & $T^{3}$ & $T^{3}-1$ & $\frac{T^{3}-1}{12}$ \\
\hline 84 & 2 & 8 & 7 & 0,5833 \\
\hline 95 & 2 & 8 & 7 & 0,5833 \\
\hline 97 & 2 & 8 & 7 & 0,5833 \\
\hline 105 & 3 & 27 & 26 & 2,1667 \\
\hline \multicolumn{6}{|c|}{ Jumlah } & 3,9167 \\
\hline
\end{tabular}

Penjumlahan faktor koreksi pada variabel $\mathrm{X}$ tersebut dimasukkan ke dalam rumus berikut:

$$
\sum_{\text {Maka: }} x^{2}=\frac{n^{3}-n}{12}-\sum T x
$$

$\sum x^{2}=\frac{n^{3}-n}{12}-\sum\left[\frac{t^{3}-t}{12}\right]$

$$
\begin{gathered}
\sum x^{2}=\frac{15^{3}-15}{12}-3,9167 \\
\sum x^{2}=\frac{3375-15}{12}-3,9167 \\
\sum x^{2}=280-3,9167 \\
\sum x^{2}=276
\end{gathered}
$$

\begin{tabular}{|c|c|c|c|c|}
\hline$Y$ & $T$ & $T^{3}$ & $T^{3}-1$ & $\frac{T^{3}-1}{12}$ \\
\hline 209 & 2 & 8 & 7 & 0,5833 \\
\hline 235 & 3 & 27 & 26 & 2,1667 \\
\hline 188 & 2 & 8 & 7 & 0,5833 \\
\hline \multicolumn{4}{|c|}{ Jumlah } & 3,3333 \\
\hline
\end{tabular}

Tabel 15

Variabel Y

Kemudian penjumlahan faktor koreksi pada variabel $\mathrm{Y}$ tersebut dimasukkan ke dalam rumus berikut:

$$
\begin{array}{r}
\sum x^{2}=\frac{n^{3}-n}{12}-\sum T y \\
\sum y^{2}=\frac{n^{3}-n}{12}-\sum\left[\frac{t^{3}-t}{12}\right]
\end{array}
$$$$
\begin{aligned}
& \sum y^{2}=\frac{15^{3}-15}{12}-3,3333 \\
& \sum y^{2}=\frac{3375-15}{12}-3,3333 \\
& \sum y^{2}=280-3,3333 \\
& \sum y^{2}=276
\end{aligned}
$$

Sesuai dengan adanya angka kembar yang terdapat pada variabel $\mathrm{X}$ 
dan variabel Y,maka rumusan $r_{S}$ dihitung sebagai berikut:

$$
r_{s}=\frac{\sum x^{2}+\sum y^{2}-\sum d i^{2}}{2 \sqrt{\left(\sum x^{2}\right)}\left(\sum y^{2}\right)}
$$

Maka:

$r_{s}=\frac{276+276-27}{2 \sqrt{(276)}(276)}$

$r_{s}=\frac{531}{9170}$

$r_{s}=0,0579$

Berdasarkan perhitungan dari korelasi Rank Spearman, harga kritis $r_{s}$ koefisien korelasi Rank Spearman untuk $\mathrm{n}=15, \alpha=0,05$ adalah 0,5140 dan nilai nilai koreksi $r_{s}$ yang digunakan adalah 0,9485 . Dengan demikian berdasarkan hasil perhitungan tersebut, dimana $r_{\text {s hitung }}>r_{\text {stabel }}$, maka $H_{O}$ ditolak dan $H_{a}$ diterima atau dapat dikatakan terdapat hubungan antara peranan audit internal yang memadai dengan pengendalian biaya produksi.

Untuk meyakinkan bahwa kedua variabel berkorelasi atau tidak, maka dilakukan uji $t$ dan hasilnya dibandingkan dengan $t_{\text {tabel }}$. Apabila $t_{\text {hitung }}$ lebih besar dari $t_{\text {tabel }}$, maka $H_{O}$ ditolak dan $H_{a}$ diterima. Perhitungan uji $\mathrm{t}$ adalah sebagai berikut:

$$
t=\frac{r_{s} \sqrt{n-2}}{1-r_{s}^{2}}
$$

Maka:

$t=\frac{0,9485 \sqrt{15-2}}{1-0,9485^{2}}$

$t=\frac{0,9485 \times 3,60}{1-0,8995}$

$t=\frac{3,4146}{0,1005}$

$t=33,97$

Untuk melihat seberapa besar variabel $\mathrm{X}$ (peranan audit internal yang memadai) dapat berperan terhadap variabel $\mathrm{Y}$ (efektivitas pengendalian internal atas biaya produksi), maka Koefisien Determinasi dari $r_{S}=0,9485$ adalah sebagai berikut:

\section{Maka:}

$K_{d}=0,9485^{2} \times 100 \%$

$K_{d}=0,8996 \times 100 \%$

$K_{d}=89,96 \%$

Artinya bahwa audit internal yang memadai sangat berperan dalam menunjang efektivitas pengendalian internal atas biaya produksi pada PT. Aqua Golden Mississippi Tbk. (Cab. Mekarsari) sebesar 89,96\%.

Hasil pengujian dibuat sesuai dengan kriteria pengujian yang telah ditetapkan pada BAB III yaitu dengan membandingkan antara nilai $t_{\text {hitung }}$ dengan nilai $t_{\text {tabel }}$ pada taraf signifikan $\alpha=0,05$ dan $\mathrm{dk}=15-2=13$ adalah 1,770 . Ini berarti bahwa nilai $t_{\text {hitung }}(33,97)>$ $t_{\text {tabel }}(1,770)$, sehingga Hipotesis Nol $\left(H_{O}\right)$ ditolak dan Hipotesis Alternatif $\left(H_{a}\right)$ diterima. Hal ini menunjukkan bahwa "peranan audit internal yang memadai berperan dalam menunjang efektivitas pengendalian internal atas biaya produksi".

Dari perhitungan diatas, dapat diambil kesimpulan bahwa pengaruh audit internal pada PT. Aqua Golden Mississippi Tbk. sangat berperan dalam menunjang efektivitas pengendalian internal atas biaya produksi, sehingga hipotesis yang penulis tetapkan yaitu "peranan audit internal yang memadai berperan dalam menunjang efektivitas pengendalian internal atas biaya produksi", dapat diterima.

\section{Penutup}

\subsection{Simpulan}

Berdasarkan hasil penelitian yang dilakukan penulis pada PT. Aqua Golden Mississippi Tbk. mengenai peranan audit internal dalam menunjang efektivitas pengendalian internal atas biaya produksi. Ditambah dengan teori-teori dasar yang dipelajari serta pembahasan yang dilakukan pada bab-bab sebelumnya, maka penulis menarik kesimpulan sebagai berikut: 
1. Peranan audit internal pada PT. Aqua Golden Mississippi telah memadai, hal ini terlihat dari:

Secara keseluruhan berdasarkan perhitungan atas pernyataan-pernyataan yang terdapat dalam kuisioner pada $\mathrm{BAB}$ $1 \mathrm{~V}$, terdapat sekitar $96,1 \%$ yang menyetujui pernyataan-pernyataan tentang kriteria audit internal, program audit internal, pemeriksaan dan evaluasi audit internal, mengkomunikasikan hasil audit internal, tindak lanjut hasil audit, kode etik audit internal, lingkungan pengendalian, penaksiran risiko, informasi dan komunikasi, aktivitas pengendalian, dan pengawasan. Dimana $47,3 \%$ responden menyatakan sangat setuju dan $48,8 \%$ responden menyatakan setuju. Ini semua mengindikasikan bahwa peranan audit internal pada PT. Aqua Golden Mississippi Tbk. (Cab. Mekarsari) telah memadai.

\section{Meskipun} secara keseluruhan peranan audit internal pada PT. Aqua Golden Mississippi Tbk. (Cab. Mekarsari) telah memadai, tetapi masih ada sekitar $3,9 \%$ responden menyatakan raguragu. Hal tersebut disebabkan oleh faktor-faktor lain yang tidak termasuk dalam penelitian yang dilakukan oleh penulis.

2. Efektivitas pengendalian internal atas biaya produksi pada PT. Aqua Golden Mississippi Tbk. (Cab. Mekarsari), hal ini terlihat dari:

Secara keseluruhan terdapat $97,02 \%$ dari responden yang menyetujui pernyataan-pernyataan mengenai efektivitas pengendalian atas biaya produksi pada PT. Aqua Golden Mississippi Tbk. Dimana $44,68 \%$ responden menyatakan sangat setuju dan $52,34 \%$ responden menyatakan setuju. Ini mengindikasikan bahwa efektivitas pengendalian atas biaya produksi pada PT. Aqua Golden Mississippi Tbk.(Cab. Mekarsari) telah berjalan secara efektif dan efisien.

Meskipun

secara

keseluruhan efektivitas pengendalian atas biaya produksi pada PT. Aqua Golden Mississippi Tbk. (Cab. Mekarsari) telah berjalan secara efektif dan efisien, tetapi masih ada sekitar 2,98\% responden menyatakan ragu-ragu. Hal ini menunjukkan bahwa belum sepenuhnya pengendalian atas biaya produksi efektif.

3. Audit Internal yang memadai sangat berperan dalam menunjang efektivitas pengendalian atas biaya produksi pada PT. Aqua Golden Mississippi Tbk. (Cab. Mekarsari), hal ini terlihat dari hasil perhitungan peranan audit yang memadai dan efektivitas pengendalian atas biaya produksi berdasarkan uji korelasi Rank Spearman yang dilakukan sebesar 0,9485 atau 94,85\%. Korelasi sebesar ini menunjukkan bahwa terdapat hubungan antara peranan audit internal yang memadai dengan efektivitas pengendalian internal atas biaya produksi adalah hubungan yang sangat kuat. Uji signifikansi yang dilakukan adalah $t_{\text {hitung }}(33,97)>$ $t_{\text {tabel }}(1,770)$, maka terbukti bahwa variabel audit internal yang memadai mempunyai hubungan yang signifikan terhadap efektivitas pengendalian atas biaya produksi.

Selanjutnya hipotesis yang menyatakan "peranan audit internal yang memadai berperan dalam menunjang efektivitas pengendalian internal atas biaya produksi" dapat diterima. Kontribusi yang diberikan oleh peranan audit internal yang memadai dengan efektivitas 
pengendalian internal atas biaya produksi diketahui melalui koefisien determinasi yaitu sebesar $89,96 \%$, sedangkan sisanya sebesar $10,04 \%$ dipengaruhi oleh faktor-faktor lain yang tidak termasuk dalam penelitian yang dilakukan oleh penulis.

\subsection{Saran}

Setelah melakukan penelitian dan pembahasan, maka penulis akan mencoba mengajukan beberapa saran perbaikan yang diharapkan dapat digunakan sebagai dasar pertimbangan atau masukkan bagi perusahaan sebagai berikut:

1. Fungsi audit internal sebaiknya terpisah dari departemen/fungsi lain dalam PT. Aqua Golden Mississippi Tbk. (Cab. Mekarsari).

2. Walaupun pemeriksaan yang dilakukan oleh bagian audit internal telah berjalan dengan baik, namun pengungkapan yang dilakukan audit internal mengenai sasaran audit pada departemen yang diaudit harus selalu diungkapkan dengan jelas dan lengkap agar mudah dimengerti serta dilaksanakan.

3. Penelitian ini hanya dilakukan pada PT. Aqua Golden MississippiTbk. (Cab. Mekarsari) yang berlokasi di Cicurug - Sukabumi, untuk itu peneliti juga menyarankan agar diadakan penelitian lebih lanjut untuk perusahaan.

\section{DAFTAR PUSTAKA}

Mulyadi. 2002. Auditing, Edisi 6, Salemba Empat, Jakarta.

Dan M. Guy, C. Wayne Alderman, dan Alan J. Winters. 2003. Auditing, Edisi 5, Erlangga, Jakarta.

Sawyer Lawrence B., Mortimer A. Dittenhofer dan James $\mathrm{H}$. Scheiner. 2005. Internal
Auditing. Alih Bahasa: Desi Adhariani. Edisi 5, Salemba Empat, Jakarta.

Andi Rahmat Taufik Babe. 2006. Peranan Audit Internal dalam Menunjang Efektivitas Pengendalian Internal Biaya Produksi (Studi Survey Pada Beberapa Perusahaan Tekstil di Bandung Timur). Universitas Widyatama, Bandung.

Unggul Trudeau. 2008. Peranan Audit Internal Dalam Menunjang Efektifitas Pengendalian Internal Penjualan Dan Pengihan Piutang (Studi Kasus Pada PT. Inti Bandung). Universitas Widyatama, Bandung.

Arens, Alvin A., Randal J. Elder dan Mark S. Beasley. 2008. Auditing dan Jasa Assurance: Pendekatan Terintergrasi. Edisi 12, Erlangga, Jakarta

Aristati Widyaningsih. 2010. Pengaruh Audit Internal Terhadap Efektivitas Pengendalian Internal Biaya Produksi (Studi Kasus PT. Dirgantara Indonesia (Persero) Bandung). Bandung.

Ratna Sari. 2010. Peranan Audit Internal Terhadap Pengendalian Intern Atas Siklus Penjualan dan Penagihan Pada PT. Pos Indonesia (Persero) Medan. Universitas Sumatra Utara, Medan.

Elder, Randal J., Mark S. Beasley, Alvin A. Arens dan Amir Abadi Jusuf. 2011. Jasa Audit dan Assurance: Pendekatan Terpadu (Adaptasi Indonesia). Alih Bahasa: Desti Fitriani. Salemba Empat, Jakarta. 
Drs. Amin Widjaja Tunggal. 2012.

Pedoman Pokok Audit

Internal. Harvarindo, Jakarta.

Wicaksono A. 2013. Ecaluasi

Pengendalian Internal Siklus

Pendapatan PT. X.

Universitas Binus, Jakarta.

Muhammad Firdaus. 2013. Peranan

Internal Audit Dalam

Meningkatkan Efektivitas

Prosedur Penagihan Piutang

(Studi Kasus Pada PT.

Cipaganti Citra Graha Divisi

Heavy Equipment).

Universitas Pasundan,

Bandung.

Drs. Danang Sunyoto. 2014. Auditing

(Pemeriksaan Akuntansi).

CAPS (Center of Academic

Publishing Service), Jakarta.

Messier, Wiliam F., Steven M. Glover dan Douglas F. Prawitt. 2014. Jasa Audit dan Assurance: Pendekatan Sistematis. Alih Bahasa: Denies Priantinah, dan Linda Kusumaning Wedari. Edisi 8, Salemba Empat, Jakarta.

Riana Agustiana Hermawan. 2015. Penentuan Harga Pokok Produksi Air Minum Dalam Kemasan $1.500 \mathrm{ml}$ Pada PT. Aqua Golden Mississippi Mekarsari. Universitas Juanda, Bogor. 